\title{
HISTORICAL AND RECENT EARTHQUAKES IN CENTRAL AMERICA
}

\author{
Wilfredo Rojas"), Hilmar Bungum²) \& Conrad Lindholm²) \\ 1) Escuela Centroamericana de Geología,Apdo. 35, 2060 \\ Universidad de Costa Rica, San José, Costa Rica \\ ${ }^{2)}$ NORSAR, The Research Council of Norway, P.O. Box 51, N-2007, Kjeller, Norway
}

\begin{abstract}
A comprehensive data base of about 17000 historical and recent earthquakes has been established for the Central American region, based on existing research and reports from Guatemala, El Salvador, Honduras, Nicaragua, Costa Rica and Panama. The catalog includes known damaging historic earthquakes, as well as the more important of the recent data, including both macroseismic and instrumental observations. The catalog starts in the beginning of the 16th century and is limited to macroseismic data (reported phenomena and associated damage) until 1902, while it for the time since then contains both macroseismic and instrumental observations. Recent local network solutions are normally included only for events above magnitude 3.5 .

The new catalog is considered to be reasonable complete for earthquakes with magnitudes $\mathrm{M}_{\mathbf{S}} \geq 5.5$ back to around year 1900, and for $M_{S} \geq 7$ back to around year 1820, and it should have the capabilities of further assisting the ongoing efforts towards a more reliable evaluation of the seismogenic potentials in the region.

The catalog information has been used in this paper for developing new relations between body wave magnitude $m_{b}$ and surface wave magnitude $M_{S}$, between $m_{b}$ and local magnitude $M_{L}$, and between $M_{S}$ and $M_{L}$. New relations have also been developed between $m_{b}, M_{S}$ and $M_{L}$ and maximum intensity $I_{\max }$, between $M_{L}$ and felt radius, and between $M_{L}$ and felt area for intensity levels between III and VIII. Such relations are potentially important for a further development and improvement of the magnitude assessments for both newer and older earthquakes, as well as for many questions related to earthquake engineering.
\end{abstract}

RESUMEN: Las investigaciones sobre la sismicidad histórica en América Central, hasta ahora, a excepción de algunos pocos casos, han sido enfocadas hacia estudios individuales por país. Sin embargo, es frecuente que las regiones limítrofes de esos países, correspondan con estructuras tectónica de importancia, lo que conduce a la necesidad de efectuar un estudio integrado de la información existente de cada país y, de esa forma, comprender mejor la situación geotectónica. Por ello, la presente investigación cristalizó en un catálogo integrando los datos históricos, con observaciones instrumentales de la sismicidad en la región, basado en investigaciones y reportes procedentes de Guatemala, El Salvador, Honduras, Nicaragua, Costa Rica y Panamá.

El presente banco de datos es considerado razonablemente completo para sismos con magnitud $\mathrm{MS}_{\mathrm{S}}$ igual o mayor de 5,5 a partir del año 1900, y para MS igual o mayor de 7,0 desde alrededor de 1820 al presente. De hecho, aún queda mucho trabajo por hacer a fin de mejorar el catálogo, en particular para los siglos XVI, XVII y XVIII, esperando que la manera con que esta base de datos ha sido organizada, pueda ser de utilidad, sirviendo como guía para futuras investigaciones que contribuyan a mejorarlo.

Aunque el propósito principal de la presente investigación fue la compilación de la información sismológica, se han incluido además algunas aplicaciones y análisis en términos de correlación entre diferentes magnitudes (M), entre $M$ e intensidades (a diferentes niveles de intensidad), entre $M$ y aceleraciones, entre $M$ y el radio de perceptibilidad y entre $\mathrm{M}$ y el área sentida. Al respecto, han sido incluidas algunas de esas correlaciones en vista de que los resultados obtenidos resultan interesantes y, porque en parte demuestran el potencial de la base de datos establecida.

La intensión del catálogo ha sido la de incluir todos los terremotos históricos que han provocado algún daño de importancia, además de los datos recientes más relevantes, incluyendo tanto la información macrosísmica como los datos provenientes de las redes de instrumentación. En la región de Centroamérica, el primer evento sísmico localizado en forma instrumental, es el de 1902 (M=7,9), en la costa pacífica de Guatemala. La información del catálogo que comprende desde el siglo XVI hasta 1902, se limita a datos macrosísmicos (basados en observaciones 
del fenómeno y daños asociados), mientras que a partir de 1902 hasta el presente contiene tanto información macrosísmica como los datos obtenidos con instrumentación.

De acuerdo con la interpretación de los registros procedentes de instrumentos sismográficos y de datos histónicos, los eventos telúricos superficiales (h menor de $20 \mathrm{~km}$ ) que causan mayor daño corresponden a los de magnitud $\mathrm{M} \mathrm{o}$ MS igual o mayor de 6. Sin embargo, hay eventos dañinos algunas veces asociados a ruptura cortical somera, ubicadas a lo largo del arco volcánico de Centroamérica, que no han sido registrados en los catálogos internacionales, a pesar de haber ocurrido durante el período instrumental. Las observaciones sugieren que esos sismos (ahora incluidos en el catálogo) generalmente poseen valores de magnitud inferiores a 6,0.

El presente catálogo sismológico de América Central, puede ser usado en una variedad de aplicaciones, en particular para el análisis del riesgo sísmico y en general, para estudios sobre el potencial sísmico de la región.

\section{INTRODUCTION}

Seismological studies began in Central America in 1888 with the installation in Costa Rica of Ewing duplex pendulums (Morales, 1989 ), and in 1896 the same type of instruments were installed in San Salvador (Alvarez, 1990). In Guatemala two Wiechert seismographs were installed in 1925 (Molina \& Villagran, 1990). In Panama the first seismographs were installed in 1904, and in 1908 two Bosh-Omori horizontal pendulum seismographs were installed (Jorgensen, 1966). In Nicaragua the first strongmotion instrument was installed in 1966 (Johansson, 1988).

Beginning in the 1970's all six of the Central American countries installed their own regional seismological networks and data centers. Recently, a close regional cooperation has been established through the CEPREDENAC organization, including extensive and open exchange of data, and with production of a common seismic bulletin.

A wealth of information about earthquake damage in the pre-instrumental period in Central America have been documented by many authors, and such reports, where we can find accounts and descriptions of the historical earthquakes, are available since the beginning of the colonial days. The purpose of the present study has been to collect and collate as much as possible of that information, with subsequent integration of instrumental data.

The best approach in that situation would have been to go back to original, primary information, and to reassess and reevaluate the felt and damage reports for each and every earthquake in a consistent way. To rely on secondary information is, in comparison, much more uncertain because it implies the integration of data evaluated in different ways and through the use of different methods and principles, and this is even more risky when the individual studies are spanning a long time period. There is a problem in this sense with all of the commonly used macroseismic parameters, where errors often have a tendency to be carried along from one work to the next one, until someone goes back to the original data.

Knowing, however, that this approach would require much more time and resources than were available, it was decided to base the compilation on earlier works, reports, evaluations and interpretations. For Central America, the first such data available dates back to the beginning of the 16th century, connected to the European colonization of the region. We still find, however, that most of the macroseismic data collected refers to the present century, securing an overlap with instrumental data which provides more reliable means for magnitude calibration of older, historical earthquakes.

In addition to the establishment of the catalog itself, the purpose of this work has also been to use some of the information collected in the investigation of relationships between the different parameters, notably magnitude, intensity, acceleration, felt radius and felt area. The catalog will be available for more detailed research along these lines, while other useful future applications could include studies of seismogenic potentials, development of a unified magnitude, evaluation of quality and completeness of the catalog, and development of earthquake recurrence models. All such studies are relevant and useful as a basis for the development of models for regional and local earthquake hazard assessments.

A more detailed description of the new earthquake catalog for Central America is given by Rojas et al. (1993). 


\section{GEOLOGIC SETTING}

Central America constitutes a narrow continental land segment between the subcontinents of North and South America, the region is subjected to intense seismic and volcanic activity, with a clear Quaternary volcanic and tectonic segmentation (Stoiber \& Carr, 1973). There are altogether six tectonic plates involved here, the North American plate, the Caribbean plate, the Cocos plate, the Nazca plate, the South America plate, and the Panama microplate. The most prominent tectonic features as shown in figure 1 are:

(1) The Caiman Trough - ChixoyPolochic-Motagua Fault Zone, which is the boundary between the Caribbean Plate to the south and the North America Plate. The motion

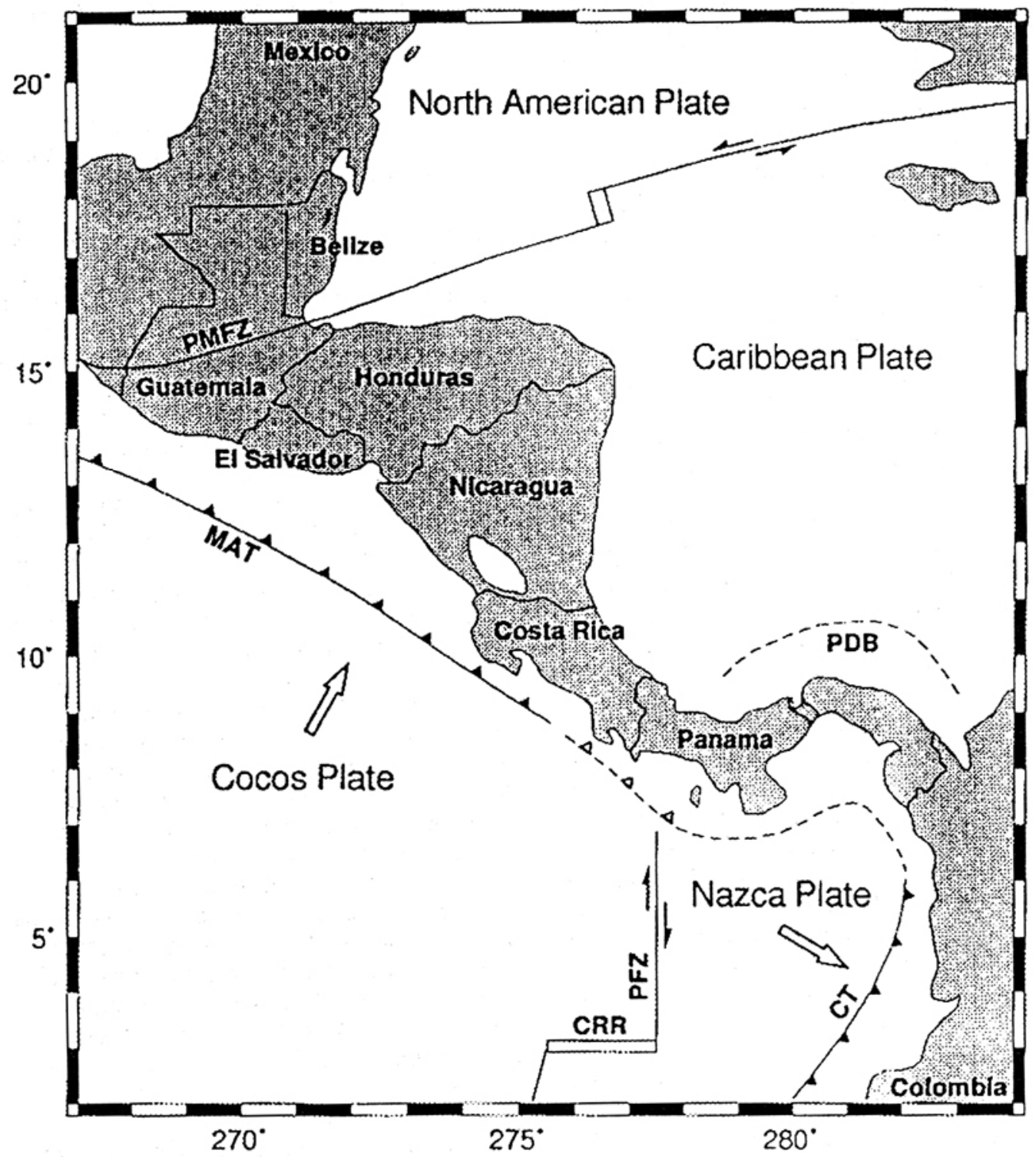

Fig. 1: A geotectonic map of Central America, with an outline of the main structures. $\mathrm{CT}=$ Colombia Trench, $\mathrm{CRR}=\mathrm{Costa}$ Rica Ridge, MAT $=$ Middle America Trench, PEZ = Panama Fracture Zone, PDB = Panama Deformed Belt; PMFZ = Polochic Motagua Fracture Zone. 
along this boundary is predominantly left lateral (Molnar \& Sykes, 1969; Kiremidjian et al., 1979).

(2) The Middle America Trench, which is the south-west boundary of the Caribbean plate, bordering to the Cocos plate. The Cocos plate is moving generally northeast and is being thrust under the Caribbean plate (Molnar \& Sykes, 1969). The Middle America Trench is a four to five kilometer deep depression located about 100 kilometer west of the pacific coast of Central America, extending from southern Mexico and southwards to Costa Rica. Along the landward margin of the trench is a band of intense and shallow seismic activity, with earthqúake foci increasing in depth to the northeast, defining a northeast dipping Benioff zone. A chain of Quaternary and active volcanoes parallels the trench and is located 100 to $200 \mathrm{~km}$ northeast of the trench and directly above the earthquakes with focal depths of about 100 to $200 \mathrm{~km}$ (Kiremidjian et al., 1977).

(3) The Panama Fracture Zone, which is a superficial right-lateral strike-slip system in north-south direction and is the east limit between Cocos and the Nazca plates (Molnar \& Sykes, 1969).

(4) The North Panama Deformed Belt, which is an overthrust boundary, is the edge of the Colombian basin overthrust by the Panama microplate. There is a north-south compression between the Panama and the Colombian basin, and it is a convergent plate boundary. However, the absence of earthquakes below $70 \mathrm{~km}$ provides no evidence for its being a real subduction zone (Adamek et al., 1988; Astorga et al., 1989). There are also the South Panama Deformed Belt and the East Panama Deformed Belt (Kolarski, 1992).

(5) The Atrato (Panama-Colombia) Suture

Zone is a thrusting type collisional zone, and located in eastern Panama near the ColombiaPanama boundary. The Panama Deformed Belt and the South Caribbean Deformed Belt join to form a southward pointing cusp lying to the north of termination of the Colombian-Ecuador trench. The faulting there is diffuse and complex, occurring probably in response to east-west compressional forces (Pennington, 1981).

Most of the Central American earthquakes are located along the five interactional boundaries just mentioned. However, an additional very important source of earthquakes in the region comes from the local faulting systems, which are found both across and parallel to the more welldefined volcanic chain. Examples of such local fault systems are the Hondurian Depression (Kiremidjian et al., 1979) and the Panama intraplate deformation, taking place within the Panama microplate (Wadge \& Burque, 1983; Adamek et al., 1988).

\section{A NEW EARTHQUAKE CATALOG}

\section{Main Sources of Information}

The work with the new earthquake catalog was initiated by making a selection for Central America from a NORSAR data base of worldwide earthquake location reports. These reports, which mostly are based on instrumental data, stem from a variety of reporting agencies, but include as a general principle not microearthquake catalogs from local networks. The most important sources of information here are the PDE (Preliminary Determination of Epicenters from the U.S. National Earthquake Information Center), and the ISC (International Seismological Center) network solutions.

The major task in the present work, to extend the data base with regional and local information from Central America, with emphasis on macroseismic data, was approached along several lines. The procedure for collecting information has been to search through data bases, publications and reports aimed at identifying and acquiring data relevant to the problem at hand, and to establish contact with seismologists and geologists from Central America and elsewhere, in particular those representing the regional observatories, in order to acquire the desired information.

In addition to the sources of instrumental data already mentioned, a wealth of information have been acquired in this study through a large number of earlier works on both historical and more recent earthquakes in the region. It is important in this respect to acknowledge the many significant older contributions, notably by De Ballore (1888), Gonzales (1910), Sapper (1925) and Dias (1930).

We have identified for Central America around 30 different earthquake catalogs, published in institute reports, journals and as bulletins in various forms. Many of these catalogs 
have been basing their work on the four earlier works just mentioned. In addition to these general catalogs, we used also a number of other more individual earthquake reports. These are identified in detail in Rojas et al. (1993), where also more than 50 different publications which have served as sources of information, are listed.

Some of the more important earthquake catalog references are, for Guatemala: Feldman (1988), Kiremidjian et al. (1977) and White (1988), for Honduras: Kiremidjian et al. (1979) and Sutch (1981), for El Salvador: Alfaro et al. (1990), Jiménez (1993) and Jordan \& Martinez (1980), for Nicaragua: Dewey \& Algermissen (1974), Larsson \& Mattson (1987) and Leeds (1974), for Costa Rica: Guendel \& McNally (1986), Miyamura (1980) and Montero (1989), for Panama: Acres (1982), Adamek et al. (1988), Jorgensen (1966), Toral (1992) and Viquez \& Toral (1987), for the Panama-Colombia Boundary: Ceresis (1986), and for all Central America: Carr \& Stoiber (1977), Feldman (1986, 1988), Kelleher et al. (1973), Peraldo \& Montero (1993), Molnar \& Sykes (1969) and White \& Harlow (1985).

\section{Data Base Organization}

For a detailed description of the format of the Central America earthquake data base we refer to Rojas et al. (1993). One of the basic ideas with this format was that it should be compatible with, and an extension of, the Nordic Standard Format. This will facilitate use of the same application programs on all types of data, old or new, and it will also make it very easy to update the database with new events. Another argument for using this format is that it allows for extended macroseismic and other information.

The main principles of the data base format are: (i) The data base will consist of one or more files where the events are listed in chronological order with respect to origin time. Updating, maintenance and access to the extra information should preferably be done via data base management programs. (ii) An event might be represented by several entries, reflecting the fact that many agencies report on the same earthquake. All reports that are available on an earthquake should in principle be stored in the database, so that the decision of which solution/report is more reliable can be taken later (by the user), dependent on region, time period, etc. (iii) The format allows for cross references, using a pointer, to other data bases and/or files that might contain information about particular events (ascii, postscript, scanner files, etc.).

In the present work the compiled data have been organized in the following types of files (for more details, see Rojas et al., 1993):

(1) The Main Catalog file, comprising the standard location parameters of the earthquakes, principally obtained from instrumental analysis, such as date, origin time, epicenter coordinates, depth, number of reporting stations, rms (rootmean-square of travel time residuals), magnitudes, and agency code. This file may also contain macroseismic information such as a geographic name, associated effects, intensity, macroseismic location, macroseismic magnitude, felt areas at different intensity levels, felt radius, quality indicator, agency code, etc. In addition, there are options for a variety of other information, including pure comment lines which may contain the pointer mentioned above to where extra information for the event can be found. This pointer is termed a 'reference key' and is a unique code connection with others files that contain supplementary information about the earthquake. Presently, this main file contains about 17,000 individual events, about 27,000 different event reports (counting duplications), and about 30,000 lines or records.

(2) The Catalog Reference file, which serves as a bridge between the main catalog file and the additional information (extensional) files. This file includes an overview of all pointers (reference keys, uniquely defined for each event) and the associated names of the files containing the supplementary information. This file contains presently around 900 entries (events).

(3) The Extensional files, containing the additional earthquake information, such as more detailed earthquake descriptions (in particular macroseismic data), bibliography references, focal mechanism solutions, associated phenomena, etc. If one such file contains additional information for more than one event, it is necessary to precede each new entry with the reference key, the format otherwise being free. While we have included all of the additional information in two files (for details, see Rojas et al., 1993), we should like to emphasize that the 
setup allows any number of extensional files, organized by country, type of information, etc., even allowing separate files for individual earthquakes. Regardless of how this is done it will still be very easy, using the computer, to pull out all available information on a particular event. The main extensional file contains about 6000 lines of descriptive text.

\section{DATA ANALYSIS AND RESULTS}

\section{Earthquakes in space and time; completeness}

A simple breakdown of the distribution over different time periods is given in Table 1 . The separation there between unlocated and located events reflects a policy by which a reasonable accuracy for the epicenter is required, even for older data, in order to have an epicenter assigned to the event. Even for the unlocated events, however, the extensional file will contain a description and a coarse indication of epicentral location.

Table 1

\begin{tabular}{|c|c|c|c|c|}
\hline Basic eart & $\begin{array}{l}\text { quake catalo } \\
\text { time peri }\end{array}$ & $\begin{array}{l}\text { statistics } \\
\text { ds from } 1\end{array}$ & $\begin{array}{l}\text { broken down } \\
505 \text { to } 1992 .\end{array}$ & $n$ different \\
\hline Years & $\begin{array}{l}\text { Unlocated } \\
\text { events }\end{array}$ & $\begin{array}{l}\text { Located } \\
\text { events }\end{array}$ & $\begin{array}{l}\text { Events with } \\
\text { magnitude }\end{array}$ & $\begin{array}{l}\text { Events with } \\
\text { intensity }\end{array}$ \\
\hline $1505-1699$ & 53 & 45 & 27 & 44 \\
\hline $1700-1799$ & 18 & 74 & 53 & 74 \\
\hline $1800-1899$ & 94 & 206 & 140 & 198 \\
\hline $1900-1959$ & 18 & 1207 & 514 & 341 \\
\hline $1960-1979$ & 1 & 5963 & 3569 & 383 \\
\hline $1980-1992$ & 0 & 9509 & 7912 & 881 \\
\hline Sum & 184 & 17004 & 12215 & 1921 \\
\hline
\end{tabular}

Table 1 also shows that magnitudes are available for most of the events, even the older ones, in which case magnitudes naturally are calculated from macroseismic observations. For many of the events there are more than one magnitude available, with reporting agency and a code which often indicates method of computation. This provides a possibility to conduct more detailed magnitude comparisons of various kinds.

The intensity data as given in the last column in Table 1 are also of different kinds. For the very oldest data, only an indication of damage or casualties is given, other times only the maximum intensity, while for the more recent data more detailed descriptions are usually provided, including tables of observed intensities, intensity maps with isoseismal contours, felt radii, felt areas, etc.

The data base is intended as a source from which subcatalogs can be selected (involving priority and quality decisions) for particular applications, and utility programs which facilitate such selections are available. An important motivation for this principle is simply that, being in a situation where a full reassessment of all original and primary data is not possible (including data for instrumental relocalizations), we don't want to make decisions which end users of the data base often are in a better position to make. In figure 2 such a selection has been done, firstly by identifying which reports that belong to the same event (using a computer program), and secondly by deleting all events that do not have at least one magnitude report $\left(\mathrm{M}_{\mathrm{S}}, \mathrm{m}_{\mathrm{b}}\right.$ or $\mathrm{M}_{\mathrm{L}}$, in that order of priority) above 3.0.

Using the same data as in figure 2 we have in figure 3 plotted only the events with magnitude $\left(\mathrm{M}_{\mathrm{S}}, \mathrm{m}_{\mathrm{b}}\right.$ or $\left.\mathrm{M}_{\mathrm{L}}\right)$ above 5.0, for two different time periods (before and after 1930). It is seen from the figure that the number of events is still very high, affecting all of the Central American countries.

In evaluations of seismic potentials for particular subregions the frequency-magnitude distribution of the data is often important. Using the whole region studied here Rojas et al. (1993) found, as expected, that the magnitude distribution does indicate a certain inhomogeneity, caused by the mixing of different seismotectonic provinces, by the mixing of different magnitudes, and by the lack of completeness for the earlier centuries. Still, the magnitude distributions indicated one 6.5 earthquake every year in the whole region when using all data since 1500 , and one 6.8 earthquake every year when using the data only since 1900 .

An analysis which complements those numbers is given in figure 4 where a timemagnitude plot which also provides a rough impression of the coverage over time of the catalog. It is seen there that the coverage often is being improved step-wise, where the development in the beginning of the 1960's is the most dramatic, leading also to a new 


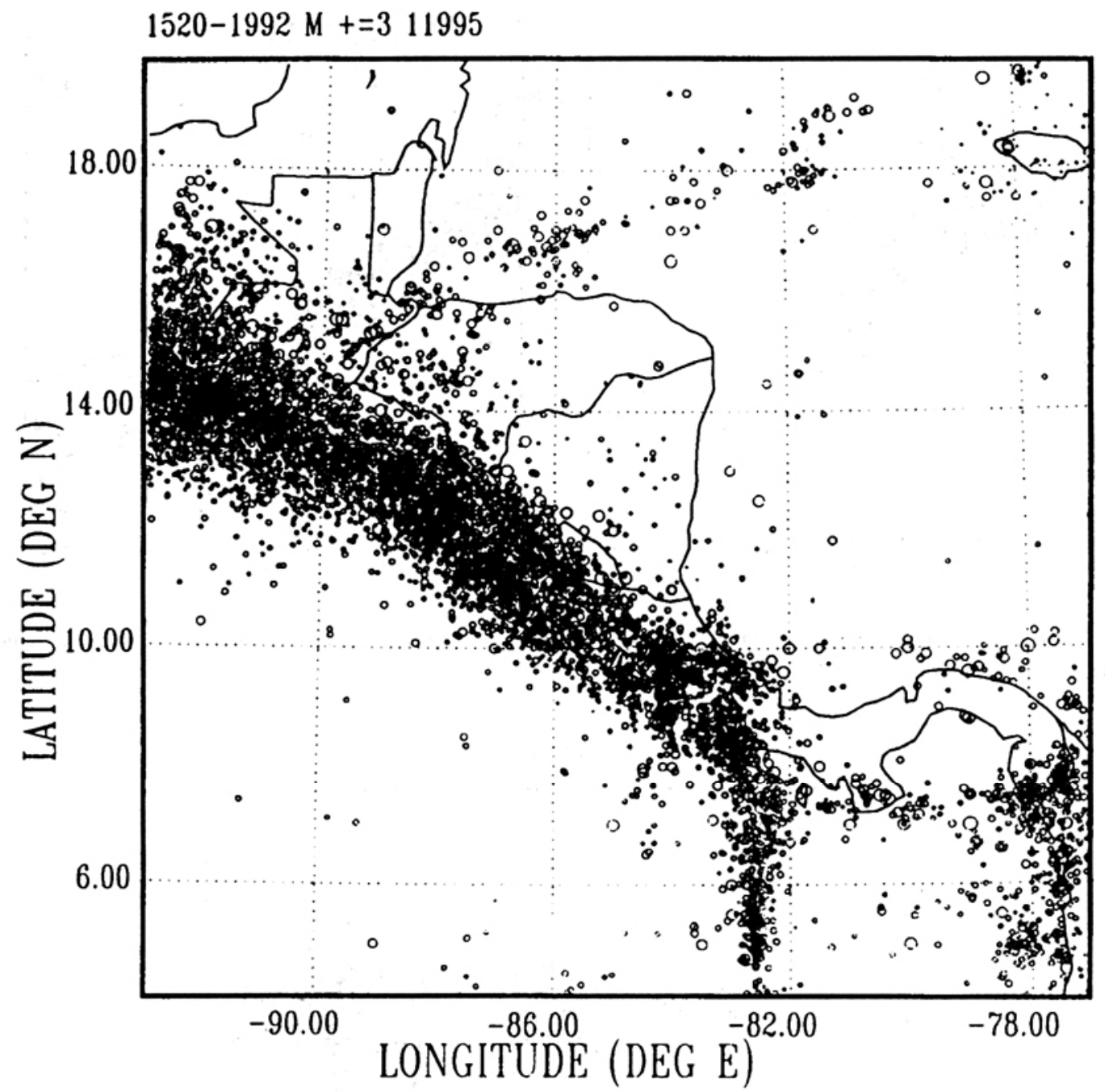

Fig. 2: The seismicity of Central America as taken from the present catalog, for a time period since 1520 , including all events with a reported $\mathrm{M}_{S}, \mathrm{~m}_{\mathrm{b}}$ or $\mathrm{M}_{\mathrm{L}}$ (in that order of priority) above 3.0. The symbols are proportional to magnitude.

understanding of global tectonics. It is seen from figure 4 that there are no earthquakes in the new catalog above magnitude 8.

A more rigorous, although simple, test for completeness was introduced by Stepp (1971), applied here with results as shown in figure 5. The test is purely statistical and based on checking the mean occurrence rate above given magnitude thresholds within consecutive time intervals of equal length (here 20-30 years), plotting on a loglog plot the standard deviation of the estimate of the mean versus the time elapsed. The technique assumes the events to be poisson distributed, in which case a complete reporting above the given magnitude threshold will maintain a reasonable constant occurrence rate, causing the standard deviation in Fig. 5 to plot parallel to dashed line with a slope of -1 . Two such plots are shown in Fig. 5, indicating that the catalog is reasonably complete above MS 5.5 back to about year 1900 , and above $\mathrm{MS}_{S} 7.0$ back to about year 1820 . Those numbers are in overall agreement with the results based on frequency-magnitude and timemagnitude distributions. 

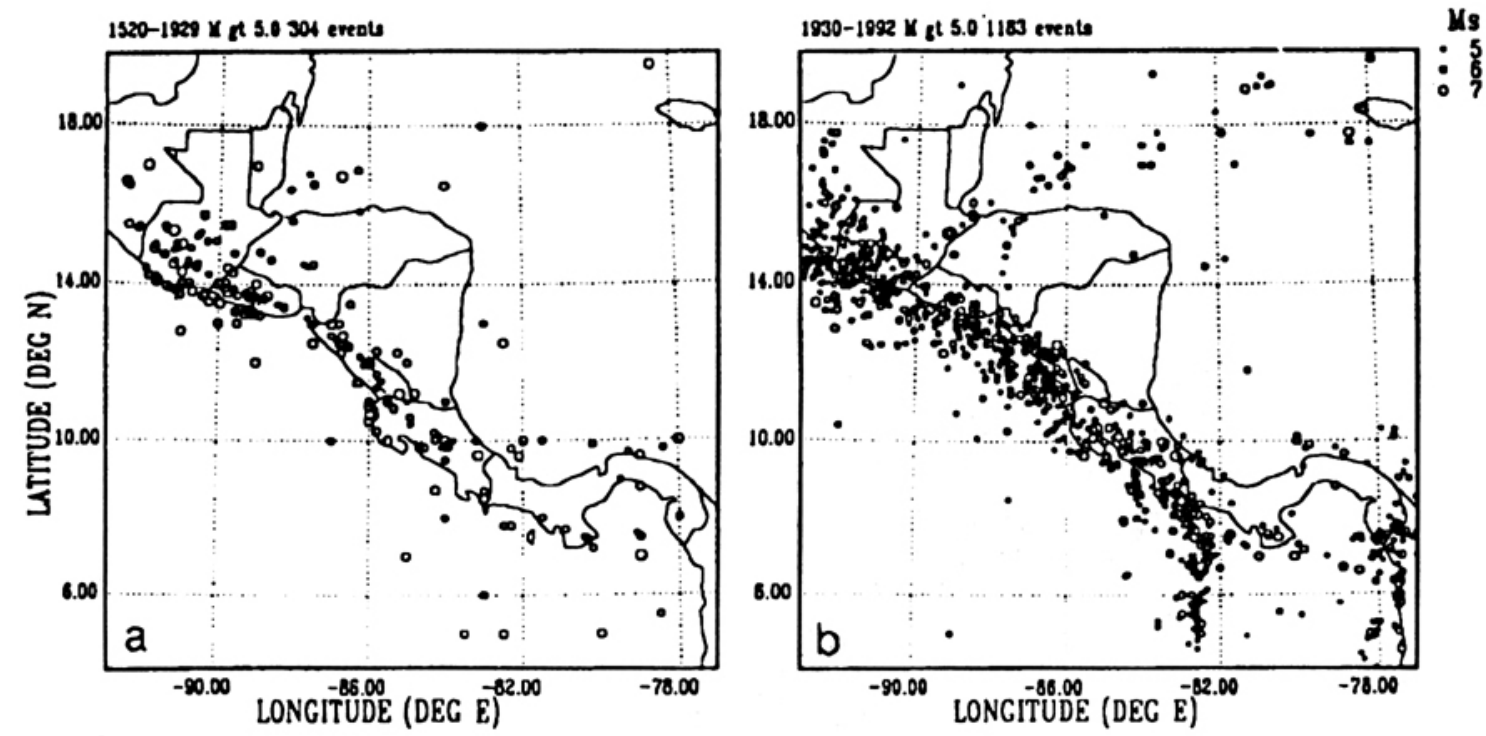

Fig. 3: Earthquakes in the present catalog with magnitudes 5.0 or above, using $\mathrm{M}_{\mathrm{S}}, \mathrm{m}_{\mathrm{b}}$, or $\mathrm{M}_{\mathrm{L}}$, in that order of priority, for a) time period 1520-1929, and b) 1930-1992.

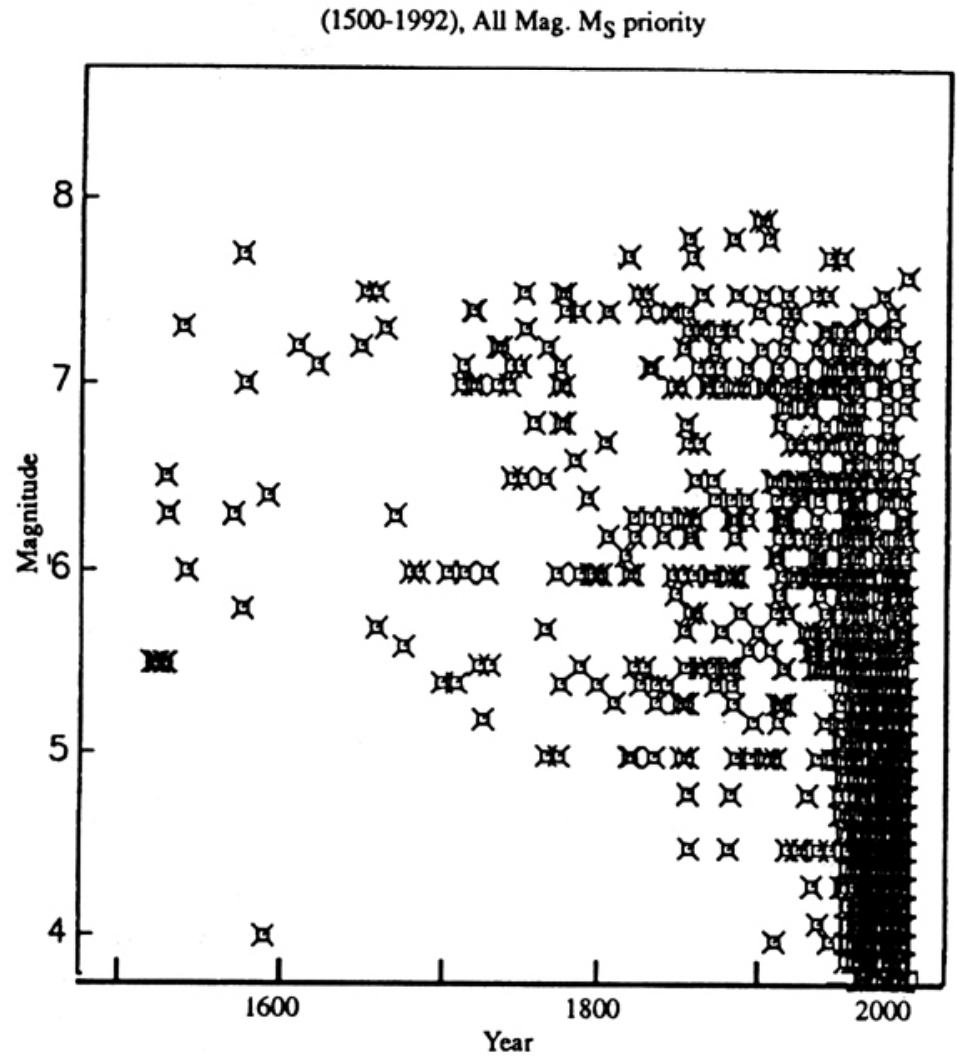

Fig. 4: Earthquake catalog distribution in time, 1500-1992, and magnitude, $\mathrm{M}_{\mathrm{S}} \geq 4.0$. 

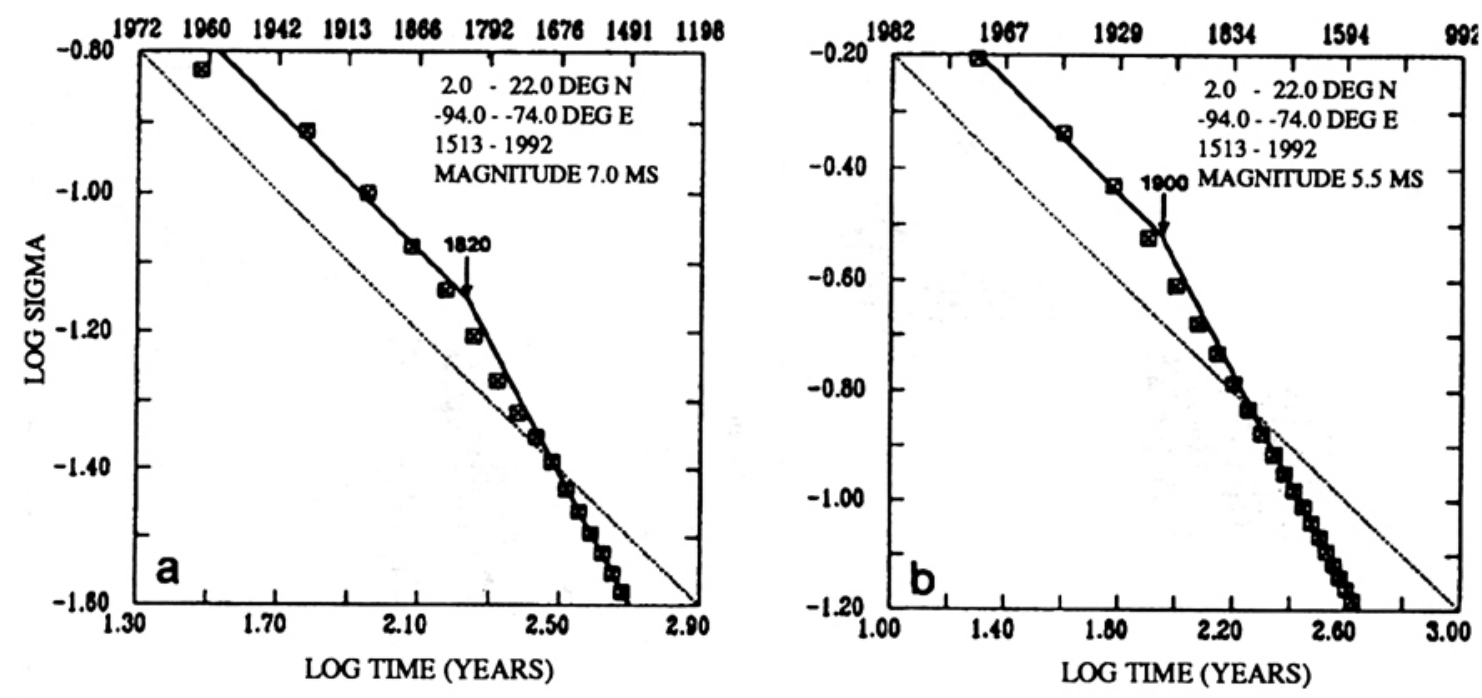

Fig. 5: Completeness analysis (Stepp, 1971) for the new Central American catalog, based on magnitudes $M_{S}, m_{b}$ and $M_{L}$ (in that order of priority) for a) $\left.\mathrm{MS}_{\mathrm{S}} \geq 5.5, \mathrm{~b}\right) \mathrm{M}_{\mathrm{S}} \geq 7.0$.

\section{Magnitude Comparisons}

The new earthquake data base for Central America (Rojas et al., 1993) contains a wealth of magnitude data of different kinds, often with many estimates for the same event. The different reporting agencies have often used different magnitude formulas, in particular with respect to local magnitude $\left(\mathrm{M}_{\mathrm{L}}, \mathrm{M}_{\mathrm{D}}, \mathrm{M}_{\mathrm{C}}\right.$, etc.), and even more variation should be expected with respect to magnitudes assigned to historical earthquakes.

The main interest initially is naturally tied to $\mathrm{M}_{\mathrm{S}}$ and $\mathrm{m}_{\mathrm{b}}$, shown for the whole region in figure $6 \mathrm{a}$ for the time period since 1963, with 927 events. The $m_{b}$ values are here all network magnitudes (ISC and/or PDE), and the MS values are surface wave magnitudes as taken from a variety of reporting agencies. The data in figure $6 \mathrm{a}$ reflect the fact that network $m_{b}$ values tend to be limited downwards for magnitudes below about $4.0-4.5$, caused by the fact that, as the number of contributing stations decrease, the remaining stations tend to be those with anomalously high amplitudes (Ringdal, 1976). To avoid some of these effects one of the regression lines in figure $6 \mathrm{a}$ include only the data above magnitude 4.0 , yielding the following relation (590 events):

$$
m_{b}=2.64+0.50 \mathrm{MS}
$$

Since this relation is orthogonal it can be inverted into an $M_{S}$ versus $m_{b}$ relation (note that error estimates for all regression coefficients estimated in this study can be found in Rojas et al., 1993). Equation (1) could be compared with the well-known relation from Gutenberg \& Richter (1956a) and with a later world-wide average from Bath (1977), reading, respectively:

$m_{b}=2.50+0.63 M_{S}$ and $m_{b}=2.94+0.55 M_{S}$.

It is seen that the new relation for Central America is reasonably close to these world-wide relations.

It is also interesting to compare $m_{b}$ with local magnitudes as done in figure $6 \mathrm{~b}$, where the $\mathrm{M}_{\mathrm{L}}$ values are taken from many different reporting agencies, using different algorithms. The scatter in the data is particularly noticeable for larger magnitudes, caused here essentially by the cases when $M_{L}$ has been estimated for subduction zone earthquakes at large distances. The magnitude regression in figure $6 \mathrm{~b}$, yields the following relation (823 events):

$$
m_{b}=0.81+0.83 M_{L}
$$


Magnitude Regression

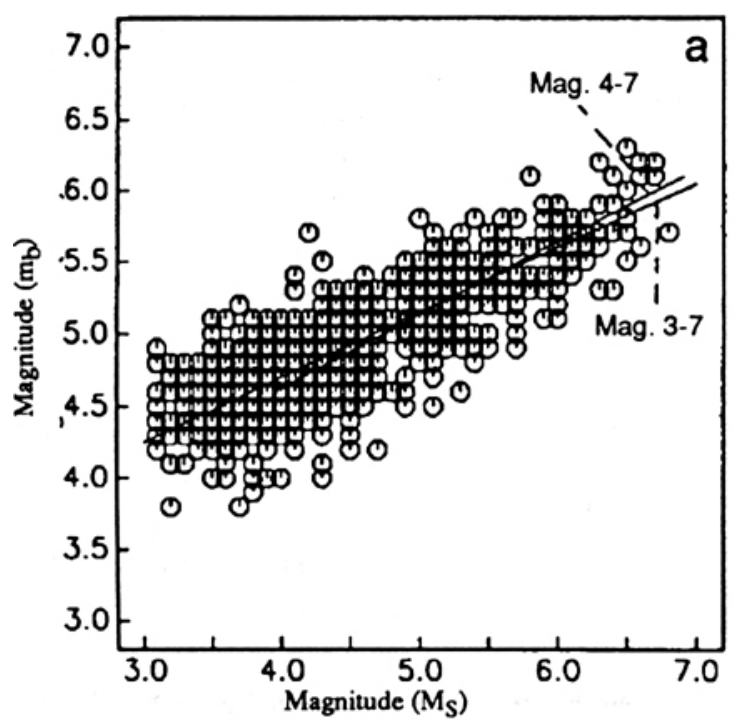

Magnitude Regression

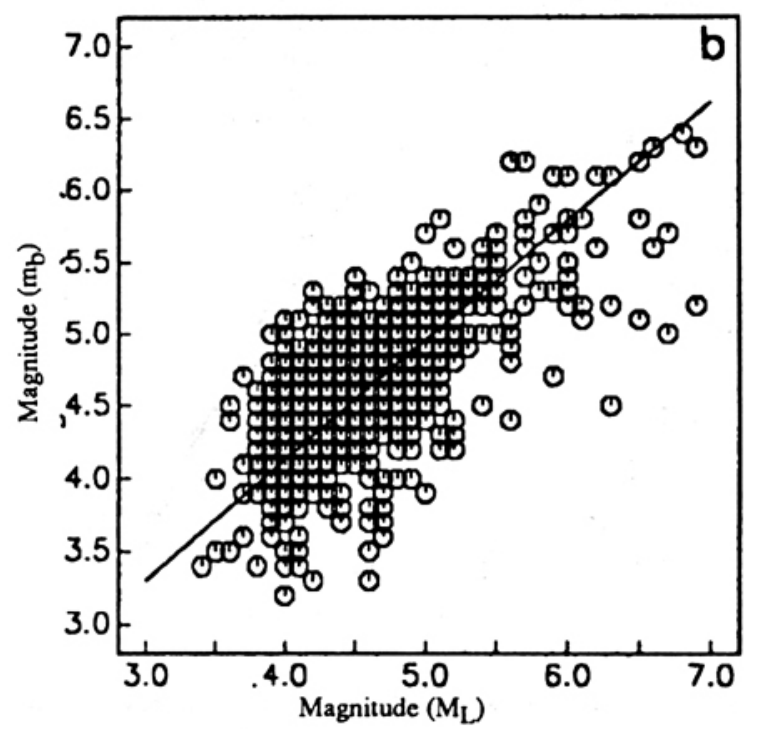

Fig. 6: Magnitude comparisons for the time period 1963-1992, for a) $m_{b}$ versus $M_{S}$, and for b) $m_{b}$ versus $M_{L}$.

Similar $\mathrm{m}_{\mathrm{b}} / \mathrm{M}_{\mathrm{L}}$ relations are more rare, but two quite different examples are one by Gibowicz (1972) for New Zealand and one by Bath (1978) for intraplate Sweden, reading, respectively:

$$
m_{b}=0.37+0.86 M_{L} \text { and } m_{b}=2.93+0.49 M_{L} \text {. }
$$

Equation (4) is between these two relations, but closer (as should be expected) to New Zealand than to Sweden. For magnitudes in the range 6-7 all three relations are quite close.

At a more local basis, further magnitude comparisons have been performed by Rojas et al. (1993) between $m_{b}$ and $M_{S}$ and local magnitude $\mathrm{M}_{\mathrm{L}}$ or $\mathrm{M}_{\mathrm{D}}$ (duration magnitude) from a number of reporting agencies in Central America. Of these, we have included here as shown in figure 7 relations between $m_{b} / M_{L}$ (277 events) and $\mathrm{M}_{\mathrm{S}} / \mathrm{M}_{\mathrm{L}}$ (137 events), based on $\mathrm{M}_{\mathrm{L}}$ magnitudes from the University of Costa Rica (Red Sismológica Nacional, ICE-UCR) since 1975:

$$
\begin{gathered}
m_{b}=0.33+0.93 M_{L} \\
M_{S}=-4.71+1.91 M_{L}
\end{gathered}
$$

It is seen from figure 7 that the scatter is quite small for these data.

\section{Magnitude and Macroseismic Information}

The new Central American earthquake catalog contains large amounts of macroseismic information and lends itself first of all to closer studies of relations between magnitude and maximum intensity, felt radius and felt area. While most of the intensity data used here are taken from earlier works, all of the felt radius and felt area data are evaluated in the present study, based on published intensity maps (see Rojas et al., 1993).

Maximum intensity is a parameter which is difficult to estimate consistently and reliably even when the criteria (the intensity scale) is welldefined, and additional problems often arise when estimates from different time periods are used. With greatly varying soil conditions such as in Central America these problems are even stronger in comparison to regions with more uniform geological conditions (such as intraplate areas). The narrow land areas in Central America also create problems in estimating both felt radii and felt areas, 
Magnitude Regression

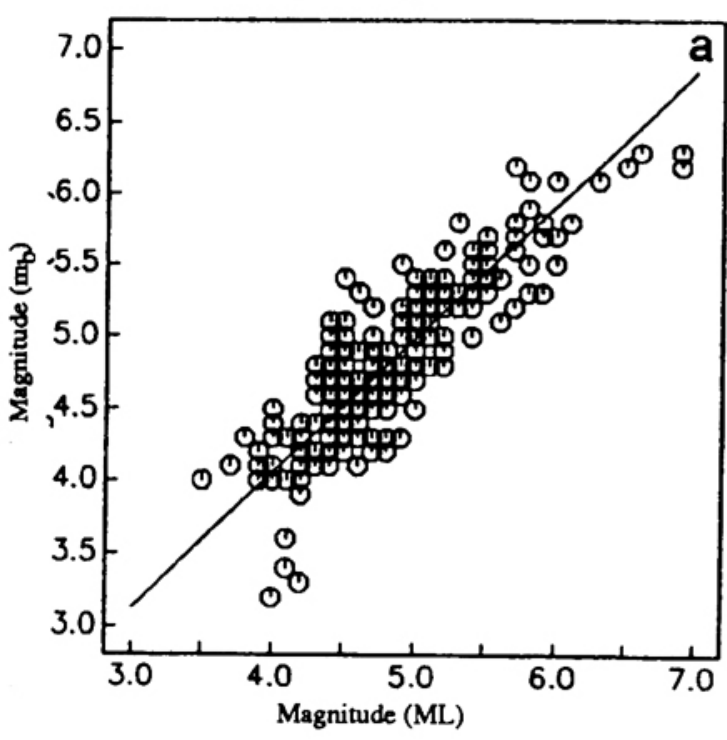

Magnitude Regression

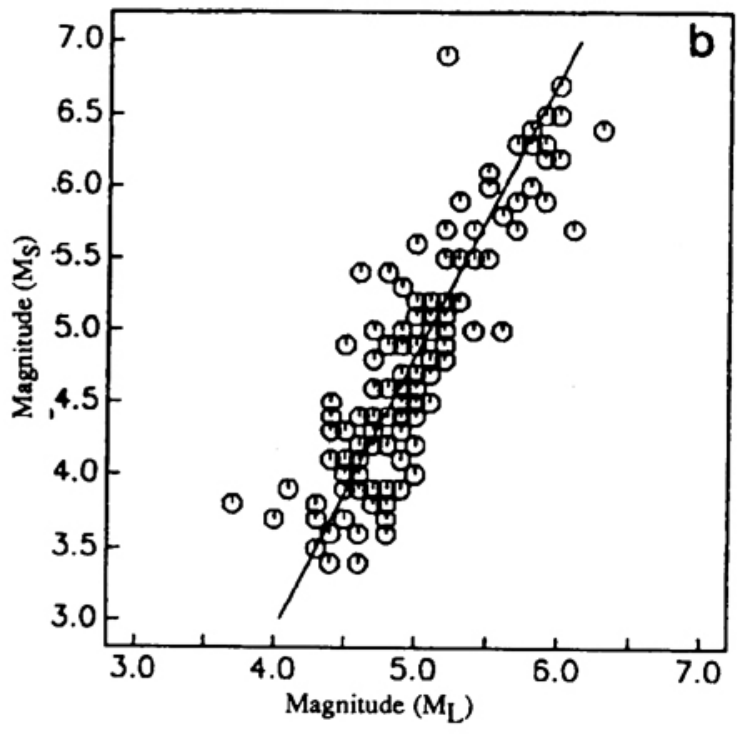

Fig. 7: Magnitude comparisons for a) $m b$ vs. $M_{L}$, and for b) $M_{S}$ vs. ' $M_{L}$, based on $M_{L}$ values from UCR-ICE, Costa Rica, for the time period 1975-1992.

since extrapolations into the sea then often are necessary. When comparisons with magnitude are made, additional sources of scatter are related to the magnitudes (see previous section).

The use of local magnitudes in Central America dates back to the early 1970's when local seismological networks started to become operational in the region. For $\mathrm{m}_{\mathrm{b}}$ and $\mathrm{M}_{\mathrm{S}}$, which are dependent on more global networks, the available estimates dates back about ten more years (to 1963), connected to the installation of the WWSSN (World Wide Standard Seismograph Network) system. Before that, most of the available magnitudes for local Central American earthquakes have been derived from macroseismic information in some form, mostly maximum intensity, and cannot of course be used for correlation with macroseismic data once more without creating dependence.

Under these limitations we find for the time period since 1963 correlations between $m_{b}, M_{S}$ and $I_{\max }$ as shown in Figure 8 , based on data that include both shallow (crustal) and deep (subduction zone) events. About half of these events are from Costa Rica, and the regressional relations are, in figure $8 a$ for $m_{b}$ (501 events):

$$
m_{b}=4.03+0.20 \mathrm{I}_{\max }
$$

and in figure $8 \mathrm{~b}$ for $\mathrm{M}_{\mathrm{S}}$ (217 events):

$$
M_{S}=3.10+0.43 I_{\max }
$$

The difference between the slopes here for $m_{b}$ and $M_{S}$ is to some extent connected to the saturation problem for $\mathrm{m}_{\mathrm{b}}$ discussed above.

In proceeding now to local magnitude $\mathrm{M}_{\mathrm{L}}$, we find that there is now enough data available since 1975 to allow a separation between shallow (depth $\leq 50 \mathrm{~km}$ ) and deep events, as shown in figures $9 a$ and $9 b$, respectively. For the shallow events in figure $9 \mathrm{a}$ the relation becomes $(555$ points):

$$
M_{L}=3.38+-0.29 \mathrm{I}_{\max }
$$

while the deep events in figure $9 \mathrm{~b}$ relate as follows (97 events):

$$
M_{L}=3.51+0.37 \mathrm{I}_{\max }
$$

These relations could be compared to similar relations from Gutenberg \& Richter (1956b) and from Toppozada (1975), which read, respectively: 

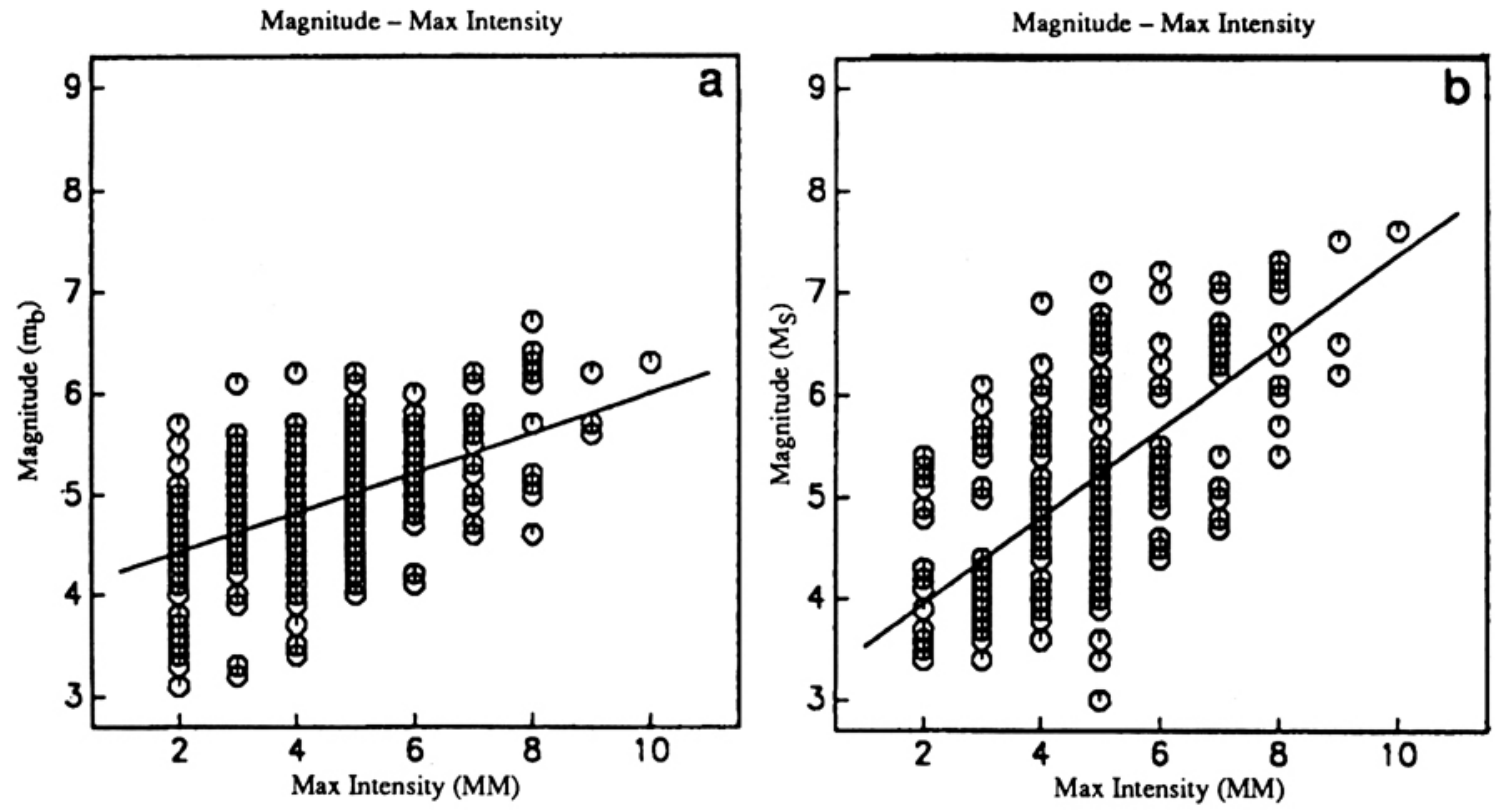

Fig. 8: Magnitude vs. maximum intensity for Central American earthquakes (both shallow and deep) for the time period since 1963 , for a) $\mathrm{m}_{\mathrm{b}}$, and b) $\mathrm{M}_{\mathrm{S}}$ (bottom).
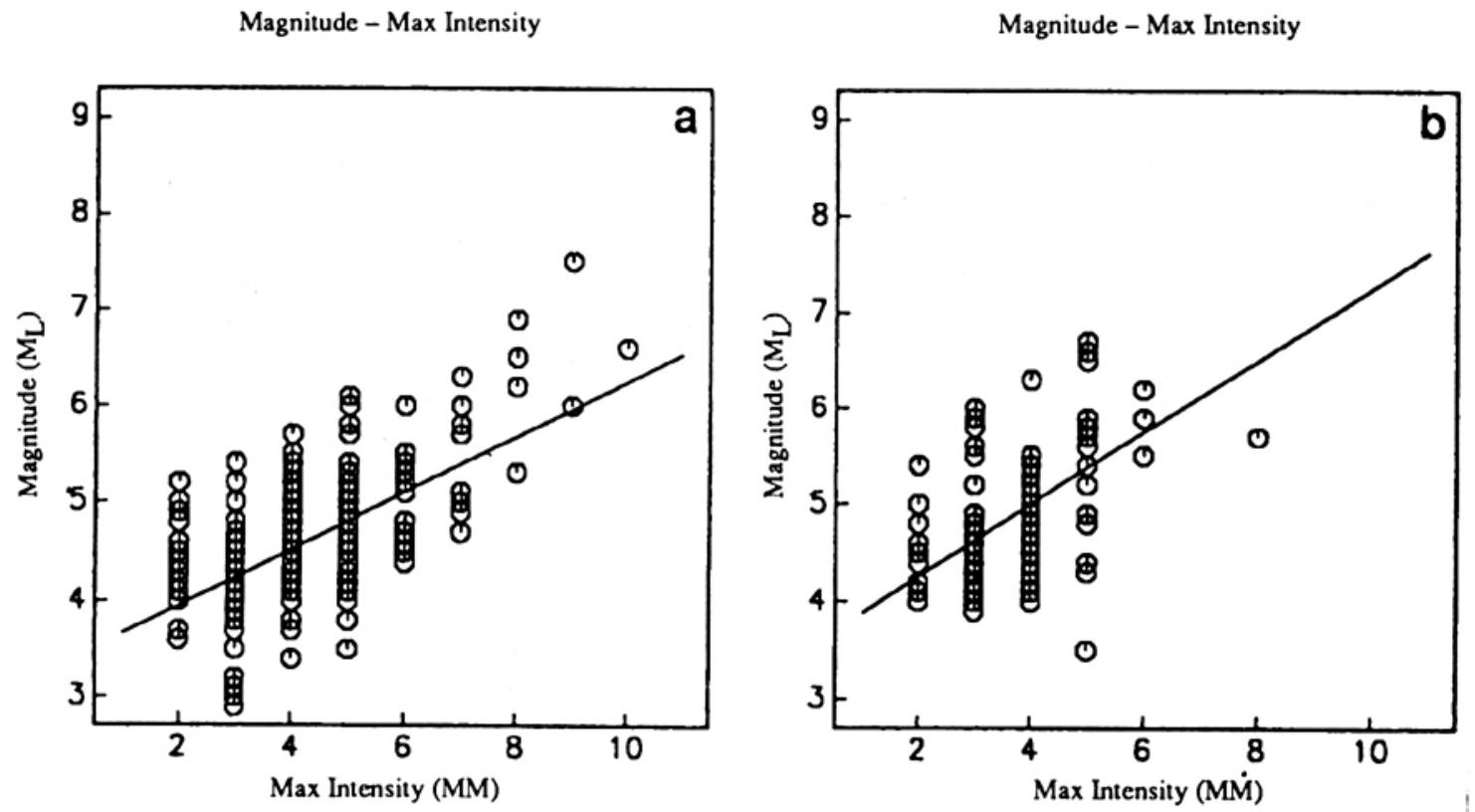

Fig. 9: Local magnitude $M_{L}$ vs. maximum intensity for Central American earthquakes for the time period since 1975, for a) shallow (crustal) events, and b) deep (subduction zone) events. 

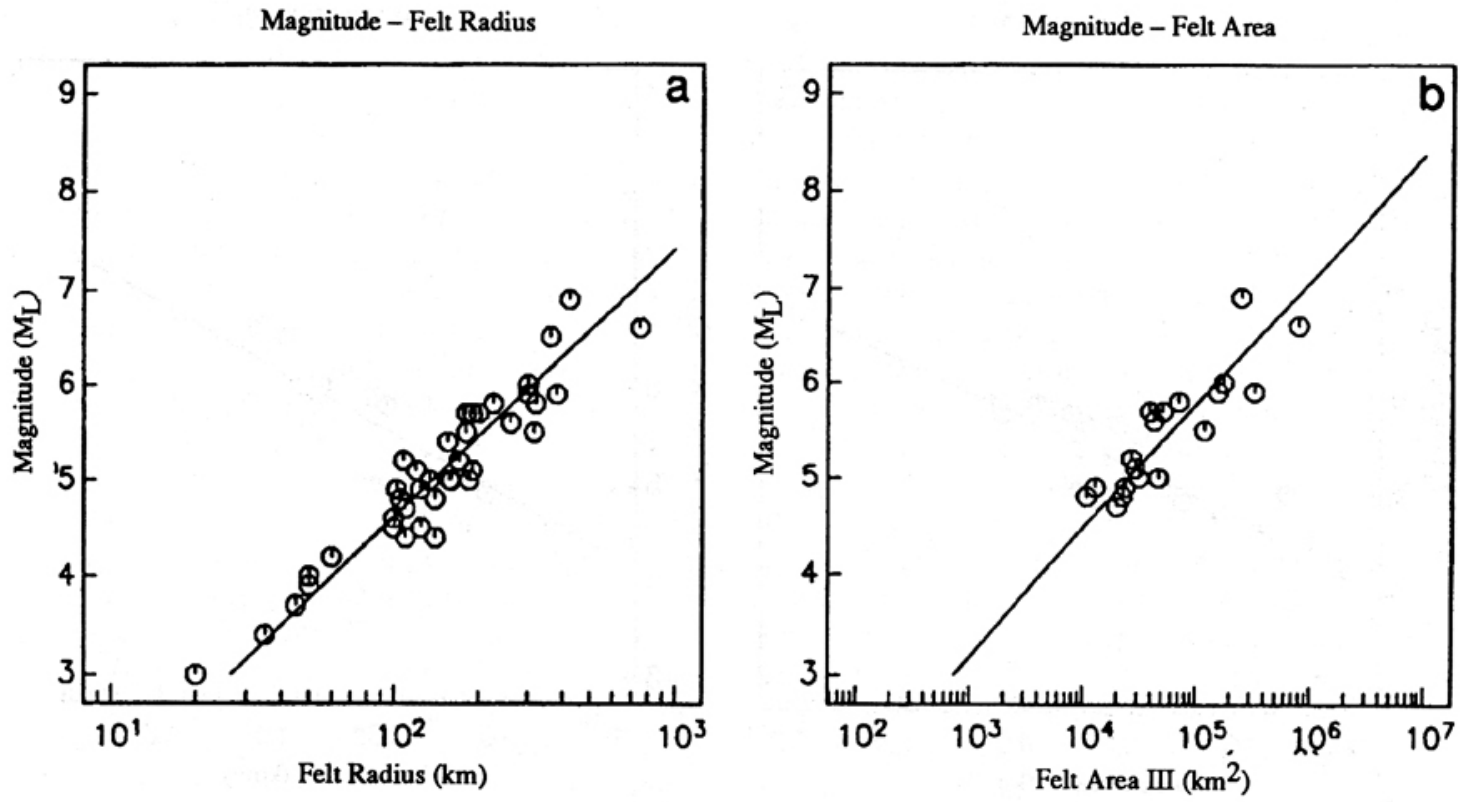

Fig. 10: Local magnitudes $M_{L}$ for Costa Rica earthquakes for the time period since 1974, vs. log felt area for intensity levewls a) IV, b) V, c) VI and d) VII.

$$
M_{L}=1+2 / 3 \mathrm{I}_{\max } \text { and } M_{L}=1.85+0.49 I_{\max }
$$

Both of these relations are significantly different from those developed in this study, but with the least deviation in the intensity range V to VII, where felt effects often are most reliably estimated.

Another commonly used macroseismic parameter for comparison with magnitude is felt radius, as shown here in figure $10 \mathrm{a}$ for Costa Rica events since 1974 , as compared to $M_{L}$ magnitudes. It is seen there that the scatter is a lot smaller, yielding this relation, where $\mathrm{R}$ is felt radius in $\mathrm{km}$ (39 events):

$$
M_{L}=-1.00+2.81 \log R
$$

Felt radius is, however, as for maximum intensity, a difficult parameter to estimate reliably, and it is therefore of great interest to investigate whether felt area could be a viable alternative here. An example is here shown in figure 10b, again for Costa Rica data since 1974, and for intensity level III. The corresponding relation is (20 events):

$$
M_{L}=-0.71+1.30 \log A_{i i i}
$$

For intensity levels IV to VII the available data (Costa Rica since 1974) are shown in figure 11a-d, the number of events are 16,18, 7 and 4, and the relations are:

$$
\begin{aligned}
& M_{L}=3.18+0.53 \log A_{i v} \\
& M_{L}=3.06+0.63 \log A_{v} \\
& M_{L}=2.96+0.80 \log A_{v i} \\
& M_{L}=2.91+0.95 \log A_{v i i}
\end{aligned}
$$

For intensity level VIII there are only 3 observations available (with independent $\mathrm{M}_{\mathrm{L}}$ estimates), yielding the following relation (no plot given here):

$$
M_{L}=5.14+0.46 \log _{\text {Aviii }}
$$

It is seen from equations (10) to (15) that the relations for intensity levels III and VIII are somewhat different from levels IV to VII, which actually reveal a very systematic and stable development of the estimated coefficients. This result is reasonable in view of the fact that levels III and VIII should be expected to be more difficult to estimate reliably, and it shows that levels IV to VII should preferably be used (at least until these relations are developed further) when applied reversely (for magnitude estimation) to older data.

The relations developed here could be compared to some similar ones developed for California and western Nevada, as published by Toppozada (1975): 

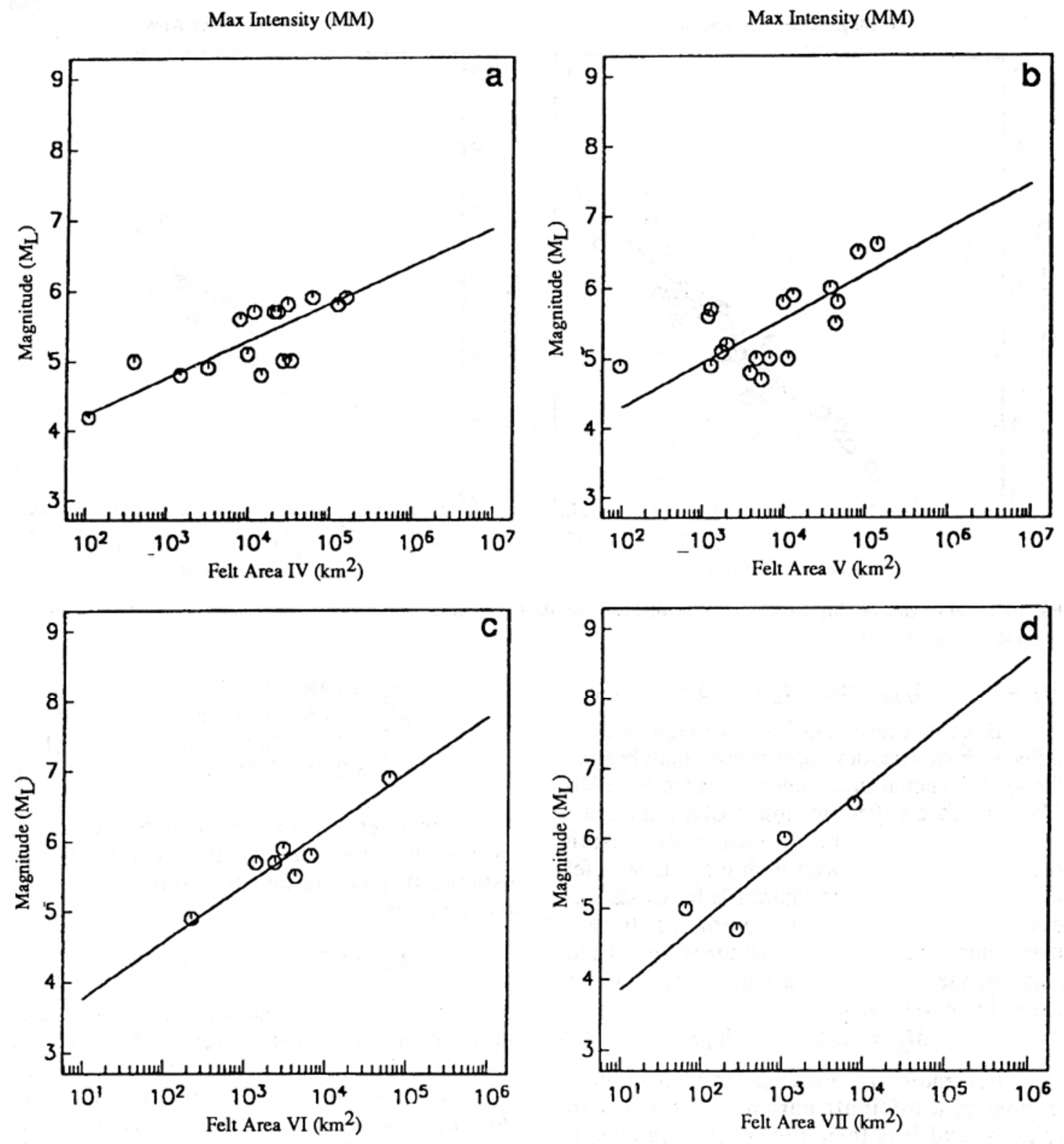

Fig. 11: Magnitude vs. felt area for different intensity levels.

$M_{L}=0.86+1.09 \log A_{v}$ and $M_{L}=2.56+0.85 \log A_{v i}$

\section{DISCUSSION AND CONCLUSIONS}

$M_{L}=3.49+0.87 \log \mathrm{A}_{v i i}$ and $M_{L}=4.30+0.87 \log A_{v i i i}$

The present work represents a major effort towards the establishment of an improved earthquake catalog for Central America, covering both historical and instrumental data. The instrumental period starts

These relations are reasonably close to the ones derived here, for Central America. in 1902, and it is worth noticing that the best quality macroseismic data also are from the last century. 
This overlap between macroseismic and instrumental data is important because macroseismic data are complementary to instrumental data and therefore contribute importantly to a better characterization of the earthquakes and their effects. Secondly, the overlap allows also the establishment of more reliable correlations between instrumental and macroseismic data, which in turn can be used as a basis for the establishment of more reliable and better calibrated magnitude scales for preinstrumental earthquakes.

The question of catalog format is of course in principle a trivial one, but not the question of what kind of information the format allows to be included, and the technical environment needed for accessing the data. The format used in this study (as documented in details by Rojas et al., 1993) is flexible and has few limitations in terms of allowing for new data to be included, the data base is still easy to access directly or by simple computer programs, and it is also compatible with the (Nordic Standard) format used for new network data by the seismological data centers in the region.

An obvious limitation with the present catalog is that it is based on earlier interpretations and therefore on data of widely varying quality, including reports that often purport conflicting views. This can, however, be turned into an advantage, leaving it to the users of the data base to develop selection and decision criteria. These selection criteria may have to be differentiated in time and space, depending upon the quality and reliability of the contributing data sources. The catalog as a whole should therefore not be expected to be very homogeneous, as indicated also by the completeness tests in this paper. There are, as briefly touched upon above, important reasons for the catalog not being homogeneous, even for more recent time periods, the primary one being that we are mixing data from widely differing tectonic regimes and processes.

Another and more trivial reason for the inhomogeneity is that the reporting capability has varied significantly both in time and space, and this applies even to the time since the national networks started to become operational in the 1970 's. However, in order to protect the data base (now counting about 17000 earthquakes) from being 'contaminated' by numerous small events we have as a general rule included local network data only for magnitudes above 3.5, keeping the weaker earthquakes (about 20000 events so far) in separate files, but in the same format.

The correlations established in this study between different magnitudes and between magnitude and the various macroseismic parameters (intensity, felt radius, felt area) are only initial estimates which should be possible to improve, refine and extend later, as more data will become available. We would like to point out, however, that the use of felt area information contains considerable potentials that probably should be better exploited in the future. One of the major goals in this respect should be the development of a more uniform magnitude scale for Central America, possibly worked out on the basis of both magnitude and intensity data. It is encouraging in this respect that many of the regressions included in this paper have surprisingly small variances, especially when considering the difficulties in assessing the felt effects in Central America, surrounded by seas and with many less accessible regions.

The catalog established here, and the associated software, are available for seismological research purposes to everyone interested in the region. It is hoped that the catalog can be developed further, by inclusion of more old data as well as the new data which now are being recorded and analyzed at the different Central American observatories. The authors should appreciate very much in this respect to be informed about bugs and errors in the existing data base, and about new information that could be included.

Acknowledgments: This work has been supported by the Norwegian Agency for International Cooperation (NORAD) through the project "Reduction of Natural Disasters in Central America, Earthquake Preparedness and Hazard Mitigation, Seismic Zonation and Earthquake Hazard Assessment". We thank the Swedish International Development Authority and the Royal Institute of Technology, Stockholm, for logistical support, and CEPREDENAC, centered in Guatemala, for their regional coordination.

We thank a large number of persons and institutions in Central America and surrounding countries for contributing with important data for this project, including F. Matzdorf, E. Molina and 
M. Villagran from Guatemala, M. Ciudad-Real from El Salvador, G. Cruz from Honduras, W. Strauch and F. Segura from Nicaragua, R. Barquero, V. Gonzales, F. Güendel, G. Peraldo and C. Redondo from Costa Rica, E. Camacho and J. Toral from Panama, and A. Sarria from Colombia. We thank also J. Tanner and J. Shepherd from the Pan American Institute for Geography and History (Canada) for important coordination and advice regarding the data compilation and for pointing out an error in the data base, and A. Dahle at NORSAR for extensive discussions and advice.

The first author thanks NORAD for a fellowship grant that allowed him to work at NORSAR for a full year to complete this work as a part of a Licentiature Thesis in Geology, and he also thanks the whole NORSAR staff for their active support during this time.

\section{REFERENCES}

Acres International, Ltd., 1982: Proyecto hidroeléctrico Tabasara, Seismic Study (Appendix C), - Technical Report, Inst. Recursos Hidráulicos y Electrificación, Rep. de Panamá.

Adamek, S., Frohlich, C. \& Pennington, W.D., 1988: Seismicity of the Caribbean-Nazca boundary: Constraints on microplate tectonics of the Panama region. - J. Geophys. Res., 93: 2053-2075.

Alfaro, G.A., Michaud, G. \& Biolley, P., 1911: Informes sobre el terremoto de Toro Amarillo, Grecia. - Boll. de Fomento, ano I, No. 7, Ag. 1911, 533-539.

Astorga, A., Fernández, J.A., Barboza, G., Campos, L., Obando, L., Aguilar, A. \& Obando, L.G., 1991: Cuencas sedimentarias de Costa Rica: Evolución geodinámica y potencial de hidrocarburos. Rev. Geol. Am. Central, 13: 25-59.

Bath, M., 1977: Teleseismic magnitude relations. - Ann. Geofis., 30: 299-327.

Bath., M., 1978: Structural and vibrational bedrock properties in Sweden. - J. Comp. Phys., 29: 344-456.
Carr, M. \& Stoiber, R. 1977: Destructive Earthquakes in Central America. - Geol. Soc. Am. Bull., 88: 151-156.

Ceresis, 1986: Catálogo de sismos frontera Colombia Panamá, area de influencia sísmica $\mathrm{R}=200 \mathrm{~km}$, MS3 (Coord. $7.5 \mathrm{~N}$ 77.5W de 1882 - 1973). - Proyecto SISRA I (Sismicidad Regional Andina. Preparado por CERESIS en colaboración con U.S.G.S., Lima. Perú.

De Ballore, M., 1888: Tremblements de Terre et eruptions volcaniques en Centre Amerique depuis la conquete espagnole jusq'a nos jours. - Dijon, Soc. des Sci. Nat. de Saone et Loire, 293 pp.

Dewey, J.W. \& Algermissen, S.T., 1974: Seismicity of the Middle America ArchTrench system near Managua, Nicaragua. Bull. Seism. Soc. Am., 64: 1033-1048.

Dias, V.M., 1930: Conmociones terrestres en la América Central 1469-1930. - Tipografía El Santuario, Ciudad de Guatemala, Guatemala, $268 \mathrm{pp}$.

Feldman, L., 1986: Master List (pre 1840) of all earthquakes and Volc. erup. en C. America. - West Georgia studies in the social sciences.

Feldman, L., 1988: Guatemalan temblores y terremotos, a catalogue. - Academia de Geografía e Historia de Guatemala. Marzo.

Gibowicz, S.J., 1972: The relationship between teleseismic body-wave magnitude $\mathrm{m}$ and local magnitude $\mathrm{M}_{\mathrm{L}}$ from New Zealand earthquakes. - Bull. Seism. Soc. Am., 63: 1557-1570.

Gonzales, C., 1910: Temblores, terremotos, inundaciones y erupciones volcánicas en Costa Rica, 1608-1910. - Tipografía de Avelino Alsina, San José, Costa Rica. 200 pp.

Güendel, F. \& McNally, C., 1986: Costa Rica earthquakes master catalog. - Charles F. Richter Lab. Univ. St. Cruz, CA, U.S.A.

Gutenberg, B. \& Richter, C.F., 1956a: Magnitude and energy of earthquakes. - Ann. Geofis., 9: $1-15$. 
Gutenberg, B. \& Richter, C.F., 1956b: Earthquake magnitude, intensity, energy, and acceleration (2nd paper). - Bull. Seism. Soc. Am., 46: 105-145.

Jimenez, T.F., 1993: Tabla cronológica preliminar de los temblores mas intensos en El Salvador. - Inst. Inv. Geotec., El Salvador.

Johansson, L.O., 1988: Seismic hazard analysis of Managua, Nicaragua. - Inst. for Jord- och Bergmekanik, MSc thesis, Kungl. Tekniska Hogskolan, Stockholm, Sweden.

Jordan, J.N. \& Martines, M., 1980: Seismic History of El Salvador - Centro de Investigaciones Geotecnicas, Depto. de Sismologia, San Salvador, El Salvador.

Jorgensen, K., 1966: Seismological History of the Canal Zone and Panama. - Balboa Heights, Canal Zone., Panama, Feb. 1966.

Kelleher, J., Sykes, L.R. \& Oliver, J., 1973: Possible Criteria for predicting earthquakes location and their application to Major Plate Boundaries of the Pacific and Caribbean. J. Geoph. Res., 78: 2547-2585.

Kolarski, R.,1992: Late Cretaceous Cenozoic Tectonics and Sedimentation in Southern Central America: Costa Rica and Panama. M.A Thesis, University of Texas at Austin, 352 pp.

Krinitzsky, E.L. \& Chang, F.K., 1977: State-ofthe-art for assessing earthquake hazard in the United States, Report: specifying peak motions for design earthquakes, U.S. Army Engineer Waterways Experiment Station, Misc. Paper S-73-1, 34 pp.

Kiremidjian, A.S., Shah, H.C. \& Lubetkin, L., 1977: Seismic hazard mapping for Guatemala. Department of Civil Engineering, - Stanford University, Report No. 25.

Larsson, T. \& Mattson, C., 1987: Nicaragua earthquake records 1975-1983. - Seismic hazard analysis in Nicaragua, pp. 127-145. Inst. for Jord- Och Bergmekanik, Kungl. Tekniska Hogskolan, Stockholm, Sweden.

Leeds, D.J., 1974: Catalog of Nicaraguan Earthquakes. - Bull. Seism. Soc. Am., 64: 1135-1158.
Miyamura, S., 1980: Sismicidad de Costa Rica. Editorial Univ. de Costa Rica. San Jose, Costa Rica.

Molina, E. \& Villagran, M., 1990: Aspectos de la Sismicidad en Guatemala. - Memorias del primer Seminario.Taller sobre sismicidad de Am. Central, Guatemala, Junio, 1989.

Molnar, P. \& Sykes, L.R., 1969: Tectonics of the Caribbean and Middle America region from local mechanism and seismicity. Bull. Geol. Soc. Am., 80: 1639-1684.

Montero, W., 1989: Sismicidad Histórica de Costa Rica 1638-1910. - Geof. Int., 28-3: 531-559.

Morales, L.D., 1989: Historia del desarrollo de las diciplinas geofísicas en Costa Rica. Hist. Ciencia y la Tecnol., Edit. Tecnol. de Costa Rica, Cartago, 225 - 271.

Pennington, W.D., 1981: Subduction of the eastern Panama basin and the of northwestern South America. - J. Geophys. Res., 86: 10753-10770.

Peraldo, G. \& Montero, W., 1993: Banco de datos sismológicos de C. Rica. - Proyecto IPGH, Esc. C. Am. Geol., Univ. C. Rica (in prep.).

Ringdal, F., 1976: Maximum-likelihood estimation of seismic magnitude. - Bull. Seism. Soc. Am., 66: 789-802.

Rojas, W., Bungum, H. \& Lindholm, C., 1993: A catalog of historical and recent earthquakes in Central America. - Report, NORSAR, Kjeller, Norway, 77 pp.

Sapper, K., 1925: Los Volcanes de la América Central. - No.1, Extra Serie. Catedra de Geografía, Univ. de Wuerzburgo, Alemania.

Stepp, J.C., 1971: Analysis of completeness of the earthquake sample in the Puget Sound area and its effect on statistical estimates of earthquake hazard. - Proc. Int. Conf. on Microzonation, Seattle, WA., Vol. 2, 897909.

Stoiber, R. \& Carr, M., 1973: Quaternary volcanic and tectonic segmentation of 
Central America. - Bull. Volcanol.,37: 304-325.

Sutch, P., 1981: Estimated intensities and probable tectonic sources of historic (pre1898) Honduran earthquakes. - Bull. Seism. Soc. Am., 71: 865-881.

Toppozada, T.R., 1975: Earthquake magnitude as a function of intensity data in California and Western Nevada. - Bull. Seism. Soc. Am., 65: 1223-1238.

Toral, J., 1992: Recostrucción histórica de la ocurrencia de terremotos y sus efectos en Panamá. - Informe de avance. Instituto de Estudios Nacionales (IDEN). Apéndice No.1 Proyecto CSUCA, Univ. de Panamá, Rep. de Panamá.
Viquez, V. \& Toral, J., 1987: Sismicidad histórica sentida en el Istmo de Panamá. - IPGH, Rev. Geofísica No. 27, Jul.-Dic. 1987, 135-166

Wadge, G. \& Burke, K., 1983: Neogene Caribbean plate rotation and associated Central American tectonic evolution. Tectonics, 2: 633- 643.

White, R. A., 1988: Catalog of historic seismicity in the vicinity of Chixoy-Polochic and Motagua fault, Guatemala. - Open file report 84-88, U.S.G.S., Menlo Park, California.

White, R. \& Harlow, D., 1985: Catalog of significant shallow earthquakes of Central America since 1900. - Proc. IASPEI Symp. Hist. Seism., Tokyo, Japan, 453-458. ... 